Waste Management \& Research (1992) 10, 345-355

\title{
RESULTS OF THE GERMAN DIOXIN MEASUREMENT PROGRAMME AT MSW INCINERATORS
}

\author{
Bernt Johnke and Eckhard Stelzner
}

\author{
Umweltbundesamt (Federal Environmental Agency), Berlin, Germany and ARGUS, Technische \\ Universität, Berlin, Germany
}

\begin{abstract}
This paper described the findings and data resulting from the German National Dioxin Measurement Programme at 11 plants with 15 incineration units. The programme's main focus was to provide answers to the question of the causes of dioxins and furans formation in the plant and to look for ways to reduce dioxin and furan emissions, including waste management measures and technical measures taken inside the plants. The investigations confirmed the finding that a major proportion of the dioxin and furan emissions is due to de novo synthesis. Two areas have to be mentioned here, the cooling zone behind the combustion chamber and the dust removal system.

Significant differences in dioxin and furan concentration levels were ascertained between variations of operating parameters, e.g. much air, little air, extremely unfavourable operating conditions (i.e. start-up and shut-down without auxiliary burners) and the normal operating conditions specific to a plant. To comply the limit

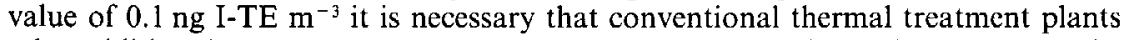
take additional measures to remove dioxins and furans from the flue gas. The measurements were carried out from 1985 to 1990. In addition, samples of fractions of household waste were analysed for their dioxins and furans.
\end{abstract}
Key Words-Dioxin measurement, PCDD/PCDF in household waste, incineration, input/output balance, waste incineration, municipal solid waste, chloro- benzene, chlorophenol, chlorofuran, Germany.

\section{Introduction}

In public debates, thermal waste treatment is considered to be an emission source burdening the environment to a disproportionately high degree, particularly because of the associated dioxin emissions. Bearing in mind the requirement that waste incineration should be used to treat waste prior to the depositing of the residues in landfills in order to relieve the pressure on the environment, it will remain necessary - not only for reasons of enhancing acceptance - to make use of all technical means through which this process technology can increasingly be used as a polutant sink.

In 1984, a working group convened by the Umweltministerkonferenz (conference of the Federal Government/Federal States ministers responsible for environmental affairs) dealt with the problem of dioxin emissions from waste incinerators. Acting on the recommendations made by this working group, systematic investigations were conducted at waste incinerators throughout the Federal Republic of Germany within the framework of a "National Dioxin Measurement Programme" supported by the Federal Minister for Research and Technology (BMFT). The programme was coordinated by the Federal Environmental Agency (Umweltbundesamt). A total of 11 plants with 15 incineration units participated. The programme's main focus was to provide answers to the question of the causes of formation of polychlorinated dibenzo-p-dioxins (PCDD) and polychlorinated dibenzofurans (PCDF) in the plants and to look for ways to reduce 
PCDD/PCDF emissions, including waste management measures and technical measures taken inside the plant. The measurements were carried out from 1985 to 1990 . In addition, samples of fractions of household waste were analysed for their PCDD/PCDF content.

In the following, the findings and data resulting from the measurement programme are presented (Johnke 1990, Greiner \& Stelzner 1991). The abbreviation "I-TE" (otherwise called I-TEQ) used in the report stands for International Toxic Equivalents according to CCMS (Committee on the Challenge of Modern Society).

\section{Relevance of the PCDD/PCDF measurement data}

The comparability of the measurement data was a question that arose especially in the overall evaluation of the measurement programme, since the sampling equipment and analytical methods used for the measurements differed. This was due to the following reasons:

- The great length of time over which the programme extended, during which numerous improvements to the measurement technology were made.

- The large number of measurement institutes and analytical laboratories participating.

- The special requirements to be met by the sampling equipment, e.g. in the combustion chamber at very high temperatures.

The basis for all sampling equipment used was the all-glass condensation method, known as the LAGA method, which was arranged as follows: filter/cooler/absorbent (LAGA 1986).

Measurements conducted in this project for comparison, as well as several parallel measurements mentioned in the literature which also included some of the sampling equipment used in the project, show fairly good agreement for the sum of PCDDs and PCDFs (Hagenmaier 1985, 1986, Hagenmaier \& Brunner 1987, Hagenmaier et al. 1987a,b, Marklund et al. 1988, 1992).

A statement as to the comparability of results of analyses for dioxins can be made on the basis of the laboratory intercomparison testing programme "dioxins in filter dusts", initiated by the VDI Committee on Air Pollution Control and coordinated by the Federal Environmental Agency. The preliminary result of this exercise, in which 18 laboratories from home and abroad participated, is stated to be a good comparability of the analytical data (Hagenmaier \& Brunner 1987a)

The uncertainties resulting from the use of differing sampling equipment and analytical methods cannot be assessed precisely. Therefore, the measurements performed at the various incineration units were, for the most part, evaluated separately. As can be seen from the measurement results, however, the differences in PCDD/PCDF concentrations between some incineration units were so pronounced that they cannot be attributed to the difference in sampling equipment or analytical methods. A sensible approach therefore seems to be to carry out an evaluation that takes all measurement data into account in a differentiated manner.

In addition to measurements during normal operation, the programme also included measurements under varied operating conditions or for waste input of varied composition. It is difficult in practice to repeatedly operate a plant under constant or comparable conditions over extended periods of time, which is also one of the reasons for the wide fluctuations that the measurement data were found to exhibit in some cases. For normal operation, a factor of two between the minimum and the maximum PCDD/PCDF concentration is to be considered normal. The statistical analysis of the data revealed 
that the interpretation of single measurement values is not sensible, but that differences in PCDD/PCDF emissions among the different operating conditions can be ascertained on the basis of mean values formed from the results of several measurement series. These differences were found to be significant in some cases. To allow well founded conclusions to be drawn, measurements should be performed three or more times under repetitive conditions.

To verify the reproducibility of PCDD/PCDF measurements, two measurement series, each consisting of five measurements, were carried out at a three-month interval in one incineration unit under normal operation. Taking into account the abovementioned fluctuations of measurement values, a sufficient reproducibility was ascertained for the mean values from the two measurement campaigns.

\section{Concentrations of PCDD/PCDF in household waste}

Investigations carried out in the past have shown that municipal wastes contain levels of PCDD/PCDF. The analyses conducted under this programme for household waste fractions representative of the original Federal States demonstrate that average concentrations must be expected to amount to $130 \mathrm{ng} \mathrm{I-TE} \mathrm{kg}^{-1}$ dry matter for paper and

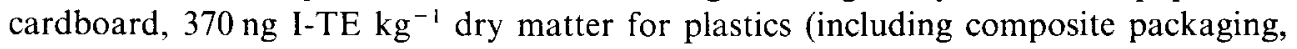
textiles, leather, wood, bone, rubber), $180 \mathrm{ng} \mathrm{I}^{-T E ~ \mathrm{~kg}^{-1}}$ dry matter for light waste (fraction passing an $8 \mathrm{~mm}$ screen) and $40 \mathrm{ng} \mathrm{I-TE} \mathrm{kg}{ }^{-1}$ dry matter for the vegetable fraction not passing an $8 \mathrm{~mm}$ screen. When estimating the contamination level of the total waste from these fraction-specific concentrations according to the various fraction's proportionate amounts in household waste, PCDD/PCDF concentrations from 11-255 ng I-TE $\mathrm{kg}^{-1}$ dry matter are obtained for waste reaching household waste incinerators. As for other organic pollutants studied, average levels in the total waste are estimated at $15-20 \mu \mathrm{g} \mathrm{kg}^{-1}$ dry matter for chlorobenzene and $260-350 \mu \mathrm{g} \mathrm{kg}^{-1}$ dry matter each for chlorophenol and PCBs.

\section{PCDD/PCDF concentrations in normal operation}

The PCDD/PCDF concentrations determined in normal operation at the incineration units studied are shown in Table 1 , even though it was not the determination of emissions but the connection between emissions and influencing factors that was the main focus of the dioxin measurement programme.

\section{Influencing factors}

\subsection{Waste composition}

The influence of specific additions to the waste or of individual waste components on $\mathrm{PCDD} / \mathrm{PCDF}$ emissions was ascertained in several incineration units. $\mathrm{HCl}$, as well as heavy metal, concentrations dropped considerably when only waste paper was incinerated. These levels rose again when scrap or scrap and PVC was added to the waste paper.

So-called fluff (light waste fraction) and waste low in PVC were incinerated in further trials. A comparison with reference measurements for normal household waste, however, reveals (as shown in Table 2) that significant decreases in PCDD/PCDF emissions cannot be achieved by changes to the composition of the waste.

The addition of PVC (1\% wt) to the waste resulted in a marked increase in $\mathrm{HCl}$ levels 
TABLE 1

$\mathrm{PCDD} / \mathrm{PCDF}$ concentrations measured in the areas/materials sampled-range and geometric mean values

\begin{tabular}{lcll}
\hline Sampling location/material sampled & $\begin{array}{c}\text { Number of measure- } \\
\text { ments }\end{array}$ & $\begin{array}{l}\text { PCDD/PCDF concentration } \\
\text { in I-TE }\end{array}$ \\
${$\cline { 1 - 2 }$} }$ & 12 & & $0.5-(1.4)^{*}-6 \mathrm{ng} \mathrm{m}^{-3}$ \\
Slag $\dagger$ (bottom ash) & 14 & & $0.0006-(0.004)-0.01 \mathrm{ng} \mathrm{g}^{-1}$ \\
Slag $\ddagger$ (bottom ash) & 14 & & $0.01-(0.03)-0.14 \mathrm{ng} \mathrm{g}^{-1}$ \\
Slag with ESP ash & 19 & & $0.38-(0.6)-0.83 \mathrm{ng} \mathrm{g}^{-1}$ \\
Water from slag removal & 6 & & $1-(9)-98 \mathrm{ng} \mathrm{l}^{-1}$ \\
Boiler ash & 25 & & $0.1-(0.2)-0.8 \mathrm{ng} \mathrm{g}^{-1}$ \\
Raw gas & 62 & & $4-(14)-39 \mathrm{ng} \mathrm{m}^{-3}$ \\
ESP ash & 54 & & $1-(4)-28 \mathrm{ng} \mathrm{g}^{-1}$ \\
ESP ash including reaction products & 19 & & $1-(2)-4 \mathrm{ng} \mathrm{g}^{-1}$ \\
from dry and semi-dry flue gas cleaning & 33 & & $2-(9)-84 \mathrm{ng} \mathrm{m}^{-3}$ \\
Raw gas following ESP & 22 & $1-(7)-106 \mathrm{ng} \mathrm{l}^{-1}$ \\
Scrub water & 11 & $2-(6)-31 \mathrm{ng} \mathrm{g}^{-1}$ \\
Filter cake & 89 & $0.2-(5)-63 \mathrm{ng} \mathrm{m}^{-3}$ \\
Stack gas (clean gas) & &
\end{tabular}

* Geometric mean values in parentheses.

$\dagger$ Levels below the detection level not included.

$\ddagger$ Levels below the detection level considered with the full detection level.

in the raw gas, but in no significant change in PCDD/PCDF concentrations. However, it cannot be concluded from this that PCDD/PCDFs do not form in the incineration of PVC. The addition of PVC caused a slight increase in the concentrations of chlorobenzene and PCBs in clean gas. A marked decrease in the concentrations of $\mathrm{HCl}$, chlorobenzenes and PCBs was achieved by the addition of lime $(1 \% \mathrm{wt})$ to the waste. The reducing influence of lime additions on the PCDD/PCDF content of electrostatic precipitator (ESP) ash and clean gas proved to be significant in some cases. Table 3 shows the effect of additions of PVC and lime on emissions.

TABLE 2

Comparison of concentrations of PCDD/PCDF, $\mathrm{HCB}, \mathrm{PCP}$ and $\mathrm{HCl}$ in raw gas for different waste compositions

\begin{tabular}{lccccc}
\hline & & \multicolumn{4}{c}{ Mean Concentrations in raw gas } \\
\cline { 3 - 6 } Variations of input & $\begin{array}{c}\text { No. of } \\
\text { measure } \\
\text { ments }\end{array}$ & $\begin{array}{c}\text { PCDD/PCDF } \\
\left(\mathrm{ng} \mathrm{m}^{-3}\right)\end{array}$ & $\begin{array}{c}\text { Hexachloro } \\
\text { benzene } \\
\left(\mu \mathrm{g} \mathrm{m}^{-3}\right)\end{array}$ & $\begin{array}{c}\text { Pentachloro } \\
\text { phenol } \\
\left(\mu \mathrm{g} \mathrm{m}^{-3}\right)\end{array}$ & $\begin{array}{c}\mathrm{HCl} \\
\left(\mathrm{mg} \mathrm{m}^{-3}\right)\end{array}$ \\
\hline Household waste & $\mathbf{3}$ & $\mathbf{5 9 0}$ & 0.3 & 7.9 & 950 \\
Waste low in PVC & $\mathbf{2}$ & $\mathbf{7 5 0}$ & 0.16 & 0.03 & 780 \\
Waste paper & $\mathbf{3}$ & $\mathbf{7 0 0}$ & 0.4 & 0.06 & 220 \\
Waste paper + scrap & 2 & $\mathbf{5 3 0}$ & 0.3 & 0.18 & 236 \\
Waste paper + scrap + PVC & 2 & $\mathbf{7 2 0}$ & $\mathbf{0 . 9}$ & 2.3 & 720 \\
\hline
\end{tabular}


TABLE 3

Comparison of the effect on emissions of materials added ( $1 \% \mathrm{wt})$ to waste

\begin{tabular}{lccccc}
\hline $\begin{array}{l}\text { Material } \\
\text { added }\end{array}$ & $\begin{array}{c}\mathrm{HCl} \\
\left(\mathrm{mg} \mathrm{m}^{-3)}\right.\end{array}$ & $\begin{array}{c}\mathrm{PCDD} / \mathrm{PCDF} \text { PCDD/PCDF } \\
\mathrm{ESP} \\
\left(\mathrm{ng} \mathrm{g}^{-1}\right)\end{array}$ & $\begin{array}{c}\text { PCBs } \\
\left(\mathrm{ng} \mathrm{m}^{-3}\right)\end{array}$ & $\begin{array}{c}\text { Chlorobenzene } \\
\text { clean gas } \\
\left(\mu \mathrm{g} \mathrm{m}^{-3}\right)\end{array}$ & $\begin{array}{c}\text { clean gas } \\
\left(\mu \mathrm{g} \mathrm{m}^{-3}\right)\end{array}$ \\
\hline Normal & 900 & 50 & 210 & 0.5 & 0.07 \\
PVC & 1600 & 60 & 290 & 15 & 0.7 \\
Lime & 400 & 30 & 120 & 0.1 & 0.005 \\
\hline
\end{tabular}

Tests involving an increased supply of bromine in the waste have also been performed; here, a distinct increase in polyhalogenated dioxin/furan levels and a slight increase in the concentrations of the chlorinated PCDD/PCDFs as well as benzenes, was ascertained.

A comparison between the incineration of municipal wastes and a mixture of waste and sewage sludge (ratio 4:1) revealed comparable PCDD/PCDF concentrations in the flue gas and in the solid residues.

\subsection{Operating conditions}

Significant differences in PCDD/PCDF concentration levels were ascertained between variations of operating parameters (e.g. much air, little air), extremely unfavourable operating conditions (e.g. start-up and shut-down without auxiliary burners) and the normal operating conditions specific to a plant. It was, however, not possible to derive direct or generally applicable correlations with often-cited individual parameters (e.g. waste throughput, load, carbon monoxide). The main problem here is that in plants operating on a commercial scale the variation of individual operating parameters causes a change of other operating parameters. Thus, it was not possible to correlate a desired optimum burnout of bottom ash and flue gas, which was monitored by means of the carbon monoxide concentration, with the PCDD/PCDF content of the raw gas. As an example, two different operating conditions are compared in Table 4.

\section{TABLE 4}

Comparison between normal operating conditions (two measurement series) and extremely unfavourable operation (two measurement series with simulation of start-up and shut-down operations without auxiliary burner)

\begin{tabular}{|c|c|c|c|c|c|c|c|}
\hline \multirow[b]{2}{*}{$\begin{array}{l}\text { Operating } \\
\text { condition }\end{array}$} & \multirow[b]{2}{*}{$\begin{array}{c}\mathrm{CO} \\
\left(\mathrm{mg} \mathrm{m}^{-3}\right)\end{array}$} & \multirow[b]{2}{*}{$\begin{array}{c}\mathrm{O}_{2} \\
\text { (vol. \%) }\end{array}$} & \multirow[b]{2}{*}{$\begin{array}{c}\mathrm{CO}_{2} \\
\text { (vol. \%) }\end{array}$} & \multirow[b]{2}{*}{$\begin{array}{l}\text { Temperature } \\
\left({ }^{\circ} \mathrm{C}\right) \text { of } \\
\text { combustion } \\
\text { chamber }\end{array}$} & \multicolumn{3}{|c|}{ Combustion chamber } \\
\hline & & & & & $\begin{array}{c}\mathrm{PCDD} / \\
\mathrm{PCDF} \\
\left(\mathrm{ng} \mathrm{m}^{-3}\right)\end{array}$ & $\begin{array}{c}\text { CB } \\
\left(\mu \mathrm{g} \mathrm{m}^{-3}\right)\end{array}$ & $\begin{array}{c}\mathrm{CP} \\
\left(\mu \mathrm{g} \mathrm{m}^{-3}\right)\end{array}$ \\
\hline Normal & 230 & 11.2 & 8.53 & 978 & 42 & 0.2 & 1.2 \\
\hline Varied & $340-1000$ & 13.3 & 6.8 & $790-870$ & 1860 & 17 & 114 \\
\hline
\end{tabular}


With respect to optimization, it can merely be concluded that a reduction of excess air while avoiding the occurrence of oxygen deficiency and inconstant combustion conditions tends to result in a decrease in PCDD/PCDF concentrations in the raw gas and ESP ash. Table 5 illustrates how the variation of total air affects the formation of PCDD/PCDFs and hexachlorobenzene.

A significant reduction in PCDD/PCDF emissions was achieved for two incineration units through fundamental modernization. the measures comprised improvements to the grates and combustion chamber geometry, continuous adjustment of combustion in both the main reaction zone and the afterburner, as well as retrofitting with an optimized flue gas cleaning system. Table 6 lists the operating parameters together with the PCDD/ PCDF concentrations in clean gas and ESP ash for one incineration unit before and after modernization.

As illustrated in Table 7, discontinuous soot blowing (once per shift) with steam (for $c$. $40 \mathrm{~min}$ ) can increase PCDD/PCDF concentrations in raw and clean gas significantly as compared with the levels in normal operation. In addition to an increase in the dust content of raw gas from $5 \mathrm{~g} \mathrm{~m}^{-3}$ to $c .34 \mathrm{~g} \mathrm{~m}^{-3}$, concentrations of the higher-chlorinated homologues were found to increase during soot blowing.

\subsection{Increasing $\mathrm{SO}_{2}$ and $\mathrm{NH}_{3}$ concentrations}

The reasoning behind the trials conducted in several incineration units to reduce PCDD/ PCDF formation by increasing sulphur dioxide $\left(\mathrm{SO}_{2}\right)$ or ammonia $\left(\mathrm{NH}_{3}\right)$ concentrations is the model of a PCDD/PCDF formation via elemental chlorine (Vogg et al. 1987). The addition of both $\mathrm{SO}_{2}$ and $\mathrm{NH}_{3}$ aimed at reducing the formation of elemental chlorine.

An increase in $\mathrm{SO}_{2}$ concentrations (from c. $200 \mathrm{mg} \mathrm{m}^{-3}$ to $c .2000 \mathrm{mg} \mathrm{m}^{-3}$ in raw gas) by the addition to sulphur to the waste input or by injection of $\mathrm{SO}_{2}$ into the second section of the boiler, caused a slight to significant decrease in PCDD/PCDF formation; this was demonstrated in three incineration lines for both raw and clean gas levels. A clear effect on ESP ash was not ascertainable. Injection of $\mathrm{NH}_{3}\left(3000 \mathrm{mg} \mathrm{m}^{-3}\right)$ into the second section of the boiler did not cause any reduction in PCDD/PCDF concentrations (two measurement series in one incineration unit). Table 8 shows the measurement results obtained for one incineration unit.

\subsection{Design characteristics, flue gas cleaning}

The investigations confirmed the finding that a major proportion of the PCDD/PCDF emissions is due to de novo synthesis. Two areas have to be mentioned here, the cooling zone behind the combustion chamber and the dust removal system. This was demonstrated by parallel measurements in the combustion chamber, in several temperature zones of the boiler, of raw gas before the electrostatic precipitator and raw gas following ESP. Table 9 shows the ranges of the PCDD/PCDF loads ascertained at several incinerators per $\mathrm{Mg}$ waste.

Measurements in an incineration unit not equipped with a steam generator, in which the flue gases were cooled off by water quenching, showed that under less than optimal combustion conditions (e.g. CO content of $250 \mathrm{mg} \mathrm{m}^{-3}, \mathrm{O}_{2}$ content of $16 \%$ ) quenching alone does not cause a reduction in PCDD/PCDF concentrations.

Various indications of the de novo synthesis of PCDD/PCDFs in the electrostatic precipitator can be derived from the measurement results. For example, it appears to be possible that the formation reaction in the ESP is dependent on temperature. The high voltage and associated ozone formation may also play a role here. 
TABLE 5

Comparison of different operating conditions as a function of total air (two to three measurement series for each operating condition)

\begin{tabular}{|c|c|c|c|c|}
\hline Operating condition & $\begin{array}{c}\mathrm{CO} \\
\left(\mathrm{mg} \mathrm{m}^{-3}\right)\end{array}$ & $\begin{array}{c}\mathrm{O}_{2} \\
\text { (vol. } \% \text { ) }\end{array}$ & $\begin{array}{c}\mathrm{PCDD} / \mathrm{PCDFs} \\
\left(\mathrm{ng} \mathrm{m}^{-3}\right)\end{array}$ & $\begin{array}{c}\text { hexachloro } \\
\text { benzene } \\
\left(\mu \mathrm{g} \mathrm{m}^{-3}\right)\end{array}$ \\
\hline Excess air $(+10 \%)$ & 70 & 10 & 1400 & 1.6 \\
\hline Starved air $(-20 \%)$ & 20 & 7 & 270 & 0.03 \\
\hline Normal & 30 & 8.5 & 590 & 0.3 \\
\hline
\end{tabular}

TABLE 6

Comparison of an incineration line before and after modernization

\begin{tabular}{lccccccc}
\hline $\begin{array}{l}\text { Incineration } \\
\text { unit }\end{array}$ & $\begin{array}{c}\mathrm{O}_{2} \\
(\%)\end{array}$ & $\begin{array}{c}\mathrm{CO} \\
\left(\mathrm{mg} \mathrm{m}^{-3}\right)\end{array}$ & $\begin{array}{c}\text { Temper- } \\
\text { ature } \\
\mathrm{ESP} \\
\left(\mathrm{C}^{\circ}\right)\end{array}$ & $\begin{array}{c}\text { Dust in } \\
\text { clean gas } \\
\left(\mathrm{mg} \mathrm{m}^{-3}\right)\end{array}$ & $\begin{array}{c}\mathrm{CH} \\
\left(\mathrm{mg} \mathrm{m}^{-3}\right)\end{array}$ & $\begin{array}{c}\text { PCDD/PCDF } \\
\text { in ESP ash } \\
\left(\mathrm{ng} \mathrm{I-TE} \mathrm{g}^{-1}\right)\end{array}$ & $\begin{array}{c}\text { PCDD/PCDF } \\
\text { in clean gas } \\
\left(\text { ng I-TE m }^{-3}\right)\end{array}$ \\
\hline Old & 16 & 250 & 270 & 20 & 13 & 2.1 & 10.5 \\
New & 11 & 40 & 160 & $<2$ & $<3$ & 1.4 & 3.8 \\
\hline
\end{tabular}

TABLE 7

Comparison of the PCDD/PCDF content of raw gas and clean gas in normal operation and during soot blowing (two measurement series each)

\begin{tabular}{lcc} 
Operating condition & $\begin{array}{c}\text { PCDD/PCDF in raw gas } \\
\left(\mathrm{ng} \mathrm{m}^{-3}\right)\end{array}$ & $\begin{array}{c}\text { PCDD/PCDF in clean gas } \\
\left(\mathrm{ng} \mathrm{m}^{-3}\right)\end{array}$ \\
\hline Normal & $600-1080$ & $13-18$ \\
Soot blowing & $17000-33000$ & $32-63$ \\
\hline
\end{tabular}

TABLE 8

PCDD/PCDF concentrations in raw gas and stack gas during normal operation and with addition of $\mathrm{SO}_{2}$ and $\mathrm{NH}_{3}$

\begin{tabular}{|c|c|c|c|c|c|c|}
\hline & \multicolumn{2}{|c|}{ Normal operations } & \multicolumn{2}{|c|}{$\mathrm{SO}_{2}$-additions } & \multicolumn{2}{|c|}{$\mathrm{NH}_{3}$-additions } \\
\hline & $\begin{array}{c}\text { Raw } \\
\text { gas }\end{array}$ & $\begin{array}{l}\text { Stack } \\
\text { gas }\end{array}$ & $\begin{array}{l}\text { Raw } \\
\text { gas }\end{array}$ & $\begin{array}{l}\text { Stack } \\
\text { gas }\end{array}$ & $\begin{array}{l}\text { Raw } \\
\text { gas }\end{array}$ & $\begin{array}{c}\text { Stack } \\
\text { gas }\end{array}$ \\
\hline $\begin{array}{l}\text { PCDD/PCDF } \\
\left(\mathrm{ng} \mathrm{m}^{-3}\right)\end{array}$ & 470 & 320 & 150 & 180 & 440 & 400 \\
\hline
\end{tabular}


TABLE 9

Range of PCDD/PCDF loads between the combustion chamber and the raw gas following dedusting

\begin{tabular}{lccc}
$\begin{array}{l}\text { Concentration in } \\
\text { combustion chamber }\end{array}$ & $\begin{array}{c}\text { Raw gas after the } \\
\text { boiler } \\
\left(\mathrm{mg} \mathrm{I-TE} \mathrm{Mg}^{-1} \text { waste) }\right.\end{array}$ & ESP ash & $\begin{array}{c}\text { Raw gas following } \\
\text { ESP }\end{array}$ \\
\hline $3-(7)^{*}-30$ & $20-(70)-190$ & $35-(115)-830$ & $12-(40)-420$ \\
\hline
\end{tabular}

* Geometric mean values in parentheses.

A factor of importance with respect to the collection efficiencies attainable in flue gas treatment is which flue gas cleaning systems are used in what combination. Table 10 shows the collection efficiencies (in per cent) achieved by various combinations, related to the concentrations of evaluated (converted to toxic equivalents) and non-evaluated PCDD/PCDFs in clean gas.

\section{Input/output balance}

In addition to representative concentration values, precise knowledge of the mass/ volume flow of the gaseous, solid and liquid residues is required to balance pollutant loads. Complete data on this was unavailable, and it was possible in any of the plants to carry out specific sampling to obtain such data. The data shown in Table 11 therefore represents an estimate of orders of magnitude from the fluctuation ranges of all 15 incineration units investigated. It is clear from the data that conventional thermal waste treatment does not constitute a sink for PCDD/PCDFs if all residual streams are included.

In Fig. 1, the output loads estimated for four incineration units on the basis of the mass/volume flows given in Table 10 are contrasted with the average input load of $80 \mu \mathrm{g}$

TABLE 10

Comparison of collection efficiencies as a function of the flue gas treatment combination used

\begin{tabular}{|c|c|c|c|}
\hline \multirow{2}{*}{ Flue gas treatment system } & \multicolumn{3}{|c|}{ Collection efficiencies $(\%)$} \\
\hline & PCDDs & PCDFs & I-TE \\
\hline ESP only & $23-77$ & $35-50$ & $35-60$ \\
\hline $\begin{array}{l}\text { Only } 1 \text { radial flow or plate } \\
\text { column scrubber }\end{array}$ & $34-70$ & $7-20$ & $5-33$ \\
\hline $\begin{array}{l}\text { ESP } / 2 \text { scrubbers (Venturi } \\
\text { or column scrubber) }\end{array}$ & 1893 & $28-96$ & $5-97$ \\
\hline $\begin{array}{l}\text { Cyclone/condition dry } \\
\text { process/fabric filter }\end{array}$ & 98 & 99 & 99 \\
\hline Semi-dry process/ESP & 83 & 60 & 66 \\
\hline $\begin{array}{l}\text { Semi-dry process/ESP/ } \\
\text { activated coke trial plant }\end{array}$ & 99.5 & 99.2 & 99 \\
\hline
\end{tabular}


TABLE 11

Balancing of PCDD/PCDF flows per $\mathrm{Mg}$ waste

\begin{tabular}{lcc}
\hline Output & $\begin{array}{c}\text { Mass/volume flow per } \\
\text { Mg waste }\end{array}$ & $\begin{array}{c}\text { PCDD/PCDF load } \\
\left(\mu \mathrm{g} \mathrm{I-TE} \mathrm{Mg}^{-1} \text { waste }\right)\end{array}$ \\
\hline Slag† (bottom ash) & $300 \mathrm{~kg}$ & $3-(9)^{*}-42$ \\
Water from slag removal & 3501 & $0.4(3)-35$ \\
Boiler ash & $7 \mathrm{~kg}$ & $0.7-(1.4)-6$ \\
ESP ash & $30 \mathrm{~kg}$ & $30-(120)-840$ \\
ESP ash + & $60 \mathrm{~kg}$ & $60-(120)-240$ \\
Scrub water & 7501 & $0.8-(5)-80$ \\
Filter cake & $8 \mathrm{~kg}$ dry matter & $15-(48)-250$ \\
Clean gas & $5000 \mathrm{~m}^{-3}$ & $1.0-(25)-300$ \\
Input (moist) & & $6.5-180$ \\
\hline
\end{tabular}

* Geometric mean values in parentheses.

$\dagger$ Levels below the detection level considered to be at the full detection level.

$\ddagger$ ESP ash plus reaction products from dry or semi-dry flue gas treatment.

I-TE $\mathrm{Mg}^{-1}$ waste. In all cases, ESP ash is the main carrier of the PCDD/PCDF output load. Even the modern unit No. 4, put into service in 1988, exhibits an approximately even balance, meaning that its function is more that of a collector and not that of a sink, in the sense of reduction. The PCDD/PCDF content can, however, be concentrated to

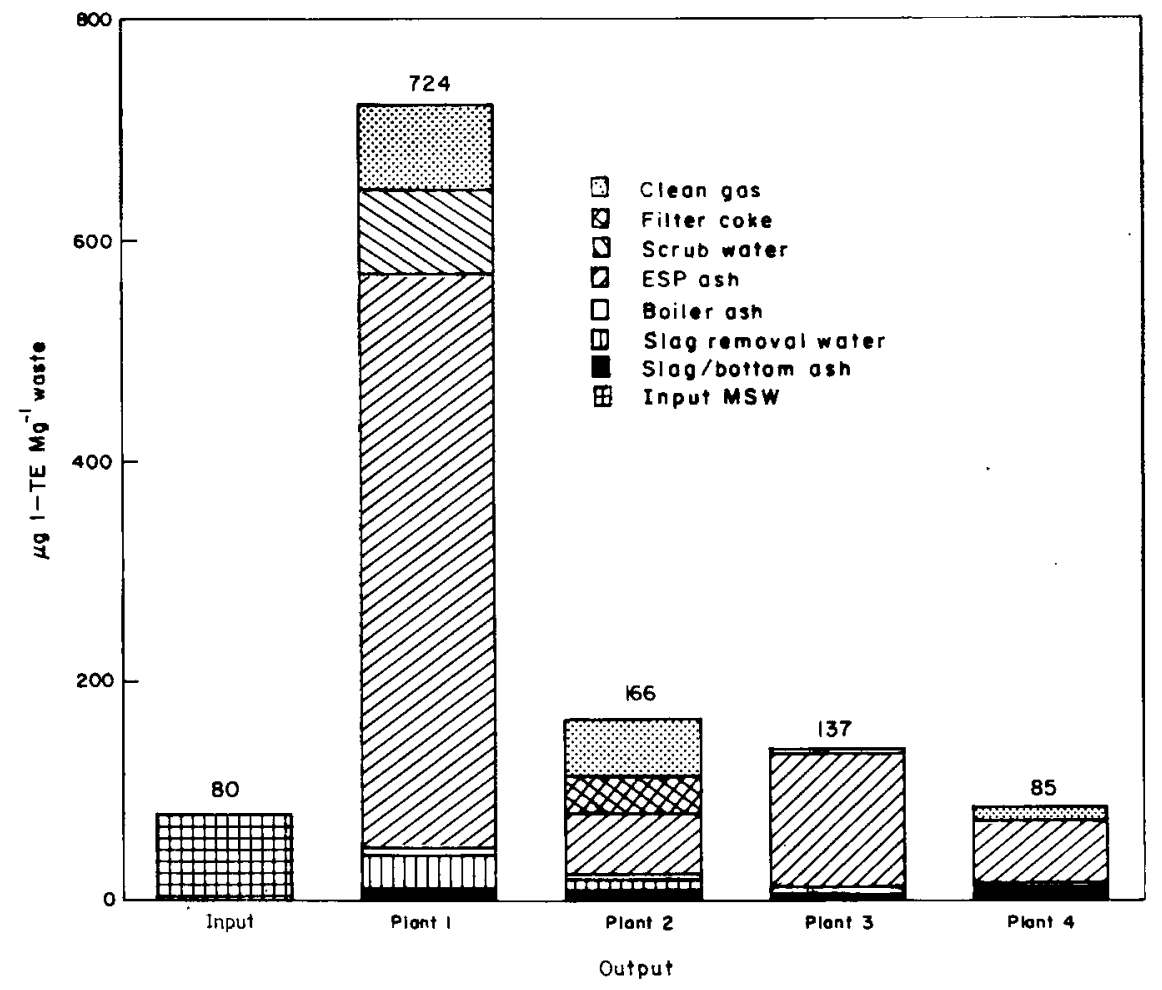

Fig. 1. 
give a minimized amount of residues which, except for the clean gas emission, can be deposited in such a way as to be no longer be bio-available. The function of a sink would only be fulfilled if the residues were to be subjected to additional post-treatment at the plants.

It can be seen from Table 12 that, for the incineration units studied, the chlorobenzene load in the output exceeds that in the input, whereas chlorophenols and especially PCBs show a decrease inside the plants.

\section{Evaluation of the results}

A multitude of findings can be derived from the results of the National Dioxin Measurement Programme, which as a whole will help improve the thermal treatment technique. The programme has furnished concrete indications to show in which parts of the plant PCDD/PCDF formation takes place and with what measures further reductions can be achieved. It was possible in some cases to confirm results obtained from laboratory investigations or plants operated on a technical scale. However, it has also become clear that the correlations often ascertained in the literature (e.g. the dependence of PCDD/PCDF formation on single parameters), or simple or unambiguous explanatory patterns regarding the formation of PCDD/PCDFs in commercial plants, are not always comprehensible. An established fact is that the formation of PCDD/PCDFs must be considered a complex process in which several mechanisms run in parallel, so that it is only possible to a limited extent to identify specific influencing factors as being decisive (Hagenmaier \& Brunner 1987). Results differing by a factor of up to two can be considered to be identical or comparable.

\section{Conclusions/perspectives}

The foremost goal in thermal treatment must be that the treatment process is run under largely controlled conditions. This includes the requirement that the burnout of both the solid and the gaseous phases is controllable. In particular, care must be taken to ensure a

TABLE 12

Input/output balance for chlorobenzene, chlorophenol and PCBs for three incineration units

\begin{tabular}{|c|c|c|c|c|c|c|c|c|}
\hline Plant & 2 & 3 & 5 & 2 & 5 & 2 & 3 & 5 \\
\hline Output & \multicolumn{3}{|c|}{$\begin{array}{l}\text { Chlorobenzene } \\
\text { (mg } \mathrm{Mg}^{-1} \text { waste }\end{array}$} & \multicolumn{2}{|c|}{$\begin{array}{c}\text { Chlorophenol } \\
\text { (mg Mg-1 waste) }\end{array}$} & \multicolumn{3}{|c|}{$\begin{array}{c}\text { PCBs } \\
\text { (mg } \mathrm{Mg}^{-1} \text { waste) }\end{array}$} \\
\hline Slag (bottom ash) & 1.7 & 1.0 & 2.9 & 17.9 & 7.0 & 0.8 & 17.2 & 15.3 \\
\hline $\begin{array}{l}\text { Water from slag } \\
\text { removal }\end{array}$ & & & 0.2 & & & & & 2.2 \\
\hline Boiler ash & 0.2 & 0.1 & & 0.05 & & 0.3 & 0.2 & \\
\hline ESP ash & 6.0 & 33.9 & 12.1 & 33.0 & 79.0 & 1.8 & 3.2 & 0.9 \\
\hline Scrub water & 0.01 & & & 0.01 & & 0.1 & & \\
\hline Filter cake & 0.2 & & & 0.08 & & 0.2 & & \\
\hline Clean gas & 15.5 & 6.1 & 2.0 & 20.0 & 7.9 & 0.1 & 0.2 & 0.4 \\
\hline Output & 23.6 & 41.1 & 17.2 & 71.1 & 93.9 & 3.3 & 20.8 & 18.8 \\
\hline Input (moist) & & 12.5 & & & 200.0 & & 200.0 & \\
\hline
\end{tabular}


high degree of destruction of PCDD/PCDFs and all organic constituents in waste, as well as the trace substances contained or forming in the raw gas. The residual content of organic carbon compounds including PCDD/PCDFs here serves as an indicator of the quality of the treatment process. Measures that should be mentioned here are above all an optimization of the grate systems and of combustion chamber geometry, as well as continuous adjustment of combustion.

In spite of all the possibilities for minimizing PCDD/PCDFs during the treatment process, it is currently not possible to completely prevent the formation of PCDD/ PCDFs and other organic compounds in parts of the plant. Therefore, conventional thermal treatment will not be able to do without additional measures to remove PCDD/ PCDF from the flue gas. A number of alternative methods are being tested here on a commercial scale, the use of which should make it possible for the limit value of $0.1 \mathrm{ng}$ I-TE $\mathrm{m}^{-3}$ prescribed by the 17 . BImSchV to be complied with continuously.

\section{References}

Greiner, B. \& Stelzner, E. (1991) Abschlußbericht zum F+E-Vorhaben: Koordinierung, Erfassung und Auswertung von Dioxinmessungen an Abfallverbrennungsanlagen (Co-ordination, Compilation and Evaluation of Dioxin Tests in MSW-Incinerators). ARGUS an der TU Berlin, Förderkennzeichen 14605 39/1. Berlin: Umweltbundesamt.

Hagenmaier, H. (1985) Vergleichende Untersuchung von Probenahmetechniken für polychlorierte Dibenzodioxine und Dibenzofurane im Abgas von Müllverbrennungsanlagen (Comparison of sampling techniques for polychlorinated dibenzodioxins and dibenzofurans in flue gas of MSW-incinerators). Forschungsbericht 14303 793/1, Part 1. Berlin: Umweltbundesamt.

Hagenmaier, H. (1986) Vergleichende Untersuchungen von Probenahmetechniken für Probenahmetechniken für polychlorierte Dibenzodioxine and Dibenzofurane im Abgas von Müllverbrennungsanlagen (Comparison of sampling techniques for polychlorinated dibenzodioxins and dibenzofurans in flue gas of MSW-incinerators). Forschungshericht 14303 793/1. Part 2. Berlin: Umweltbundesamt.

Hagenmaier, H., Brunner, H., Haag, R., Kraft, M. \& Lutzke, K. (1987a) Problems associated with the measurement of PCDD and PCDF emissions from waste incineration plants. Waste Management \& Research 5, 239-250.

Hagenmaier, H. et al. (1987b) Studies towards validated sampling of PCDD and PCDF in stack gas. In The 7 th International Symposium on chlorinated Dioxins and Related Compound, Dioxin '87, Las Vegas, U.S.A. (unpublished).

Hagenmaier, H. \& Brunner, H. (1987) Stand der Dioxinanalytik (State of Dioxinanalysis). VDIBerichte Nr. 634, Dioxin, pp. 61-90. Düsseldorf, Germany: VDI Verlag.

Johnke, B. (1990) Dioxinemissionen aus Hausmüllverbrennungsanlagen (Dioxin emissions of municipal solid waste incinerators) Heft 6 pp. 417-419, 487-490. Essen, Germany: VGB Kraftwerkstechnik GmbH.

LAGA (1986) Länderarbeitsgemeinschaft Abfall (ed.) Empfehlungen für die Probenahme sur Untersuchung von Rückständen und Abgasen aus Müllverbrennungsanlagen auf Gehalt von PCDD und PCDF (Recommendations of sampling to analysis treatment products and flue gases from MSW-Incinerators on the content of PCDD and PCDF). Stand 11/86, Handbuch Müll- und Abfallbeseitigung Lfg. 3/87: Kz. 1865. Berlin, Germany: Erich Schmidt Verlag.

Marklund, S et al. (1992) Parallel sampling using various sampling techniques at a Swedish MSW incinerator, Waste Managernent \& Research 10, 21-36.

Vogg, H., Metzger, M. \& Stieglitz, L. (1987) Recent findings on the formation and decomposition of PCDD/PCDF in municipal solid waste incineration. Waste Management \& Research $\mathbf{5}$, 285-294. 